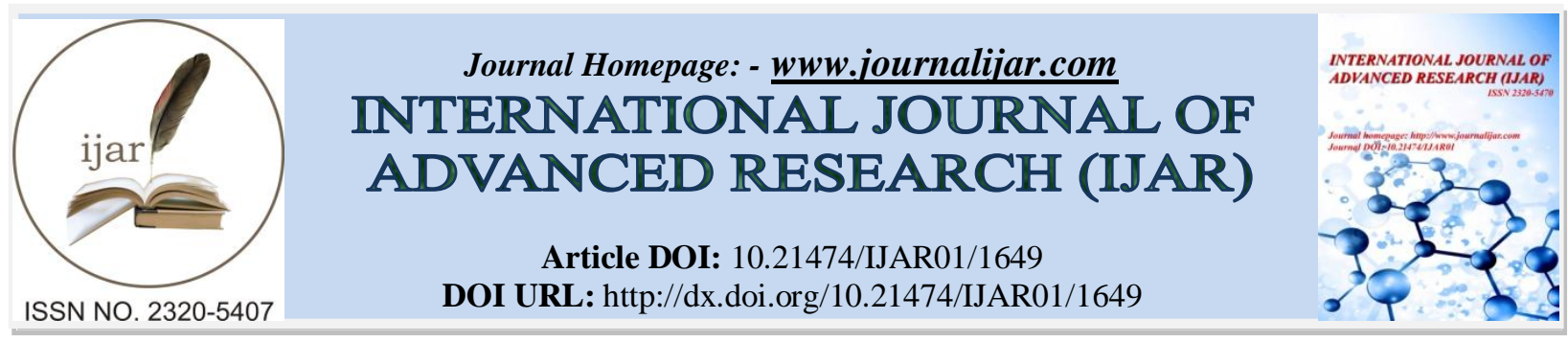

RESEARCH ARTICLE

\title{
INFLUENCE OF CHLORELLA AND SCENEDESMUS ALGAL EXTRACTS ON THE ECONOMIC TRAITS OF SILKWORM, BOMBYX MORI L.
}

\author{
V.K. Stanley Raja* and S. Abraham Muthu Kumar. \\ Department of Botany, St. Johns college, Palayamkottai, Tamilnadu, India.
}

Manuscript Info
Manuscript History
Received: 12 July 2016
Final Accepted: 19 August 2016
Published: September 2016
Key words:-
Sericulture, Chlorella pyrenoidosa,
Scenedesmus dimorphus, Bombyx mori,
Economic traits.

\section{Manuscript Info}

Economic traits.

\begin{abstract}
Silkworm Bombyx mori L. feeds on the leaves of mulberry tree which is only the host plant for silkworm. The improvement of larval feeding is enrichment of mulberry leaves with supplementary nutrients. The present study has been aimed at investigating various economic traits of the silkworm cocoon, when fed on mulberry leaves fortified with Chlorella and Scenedesmus algal extracts. The algal extracts was diluted by different concentrations $2 \%, 4 \%, 6 \%$ and $8 \%$ fed once a day from 3rd instar onwards, respectively. In was significantly increased the larvae, economic traits like cocoon weight, shell weight, pupa weight, shell percentage, filament length, fibroin, sericin and denier of silk filament.
\end{abstract}

Copy Right, IJAR, 2016,. All rights reserved.

\section{Introduction:-}

According to Chinese records, the discovery of silk production from B.mori occurred about 2700BC, making the start of the history of silk. Bombyx mori is the common mulberry silkworm that can be easily domesticated. Sericulture depends on mulberry leaves as the sole natural food of the silkworm Bombyx mori L., and the quality of the mulberry leaves has a direct bearing on the normal growth of the larvae and the quality of the cocoon (Horie $e t$ al., 1967). Masthan et al., (2011) found the growth and development of larvae, and subsequent cocoon production, are greatly influenced by the nutritional quality of mulberry leaves. Nutrition is the single most factor that influences the growth and development of B. mori (Laskar and Datta, 2000; Kanafi et al., 2007). Nutritional supplements include vitamins, amino acids, protiens and probiotics when added to larval feed tend to increase nutritional efficiency and economic traits of silkworm (Etebary and Matindoost, 2005; Amalarani et al., 2011; Singh et al., 2005).

Recently many attempts have been made to fortify mulberry leaves with botanical extracts so as to improve the mulberry leaf quality and feed efficiency of silkworm, which inturn help to increase cocoon production and silk quality. The Xanthium indicum plant extract influenced the larval and cocoon characteristics of silkworm, Bombyx mori (Pardeshi and Bajad, 2014). A commercial herbal tonic 'logen" having the extracts of some selected medicinal plants reflected into better response from the larvae of Bombyx mori (L) (Balamurugan and Isaiarasu, 2007). The silkworm larvae fed on mulberry leaves treated with Coffea arabica leaf extracts at 1:25 concentration recorded significantly higher shell weight $(0.296 \mathrm{~g})$ than control (Jeyapaul et al., 2003). The reserpine of Rauwolfia serpentina plays a stimulative role in an increase in the length of cocoon (Sujatha and Rao, 2002). Mulberry leaf supplemented with Spirulina as a feed to Bombyx mori L. (Lepidoptera: Bombycidae) oraly found to be effective in enhancing the larval and cocoon characters (Venkataramana, 2003). 
Chlorella pyrenoidosa is a species of the freshwater green algae genus Chlorella. The species name pyrenoidosa refers to the presence of a prominent pyrenoid within the Chlorella chloroplast. It has the highest content of chlorophyll of any known plant and also contains high concentration certain vitamins, proteins, minerals, dietary fiber, nucleic acids, aminoacids, enzymes and other substances. Scenedesmus dimorphus is a freshwater unicellular green algae in the class Chlorophyceae. The name means "having two forms" (Guiry and Guiry, 2011). The Scenedesmus dimorphus contains proteins, carbohydrates and lipids.

In recent many attempts have been made in sericulture with nutrient such as protein, vitamin, carbohydrates, amino acids, vitamins etc for better performance of good quality of cocoons (Sanappa et al., 2002). In addition to mulberry leaves feed supplements are also given to silkworm to enhance economic characteristics (Jayapaul et al., 2003, Sheeba et al., 2006). The present study is an attempt to evaluate the influence of Chlorella and Scenedesmus algal extracts on the economic traits of Silkworm, Bombyx mori L.

\section{Materials and Method:-}

The diseased free eggs of silkworm B. mori bivoltine hybrid (CSR2XCSR4) race were procured from district sericulture office, Konam, Nagercoil.

\section{Silkworm Rearing:-}

In the present investigation rearing operations were carried out according to (Krishnaswami, 1978). Silkworms were reared under standard recommended condition at $26+2^{\circ} \mathrm{C}$ temperature, $75 \%$ relative humidity. They were fed with MR2 variety of Mulberry leaves.

\section{Algal extracts Treatment:-}

The Chlorella and Scenedesmus algal extracts were cultured from Gideon research lab, Nagercoil. Freshly moulted III instar larvae were divided into five group of 50 worms each. One group served as control and the others were used for experimental trails with $2 \%, 4 \%, 6 \%$ and $8 \%$ of algal extracts fed to III, IV and V instar larvae, once in a day.

\section{Economic traits of cocoons:-}

The cocoons were matured at 7 to 10 days, after the $5^{\text {th }}$ instar was completed. Some important economic traits of sericulture, such as the cocoon weight, shell weight, pupal weight, shell ratio and silk characters like fibroin content, sericin content, filament length and denier were recorded and the data were calculated by the following formulas. Data were analyzed as means \pm SD. P values $<0.05$ were regarded as statistically significant.

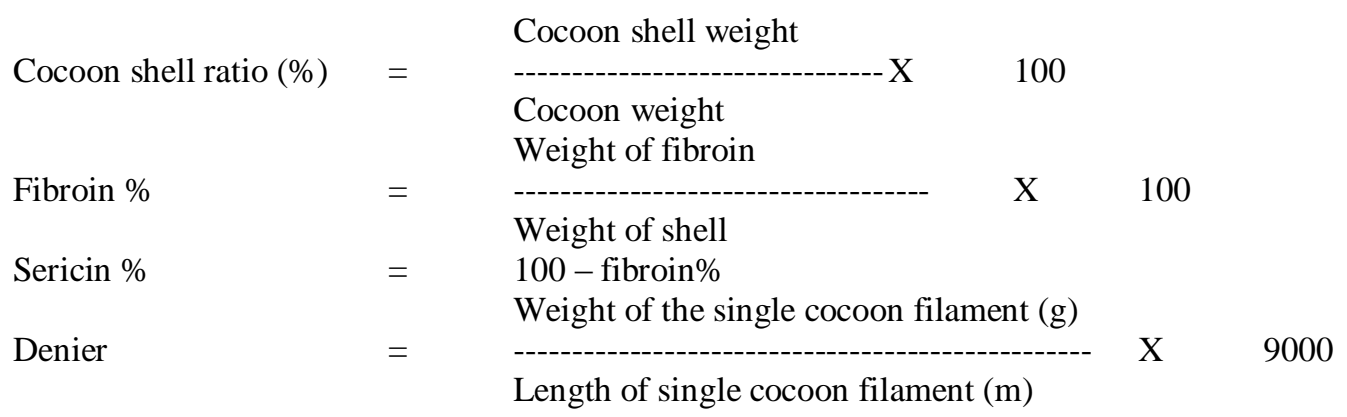

\section{Results and Discussion:-}

The influence of Chlorella and Scenedesmus algal extracts supplementation on the mulberry leaves were analyse of four treatments showed significant changes in the values against control batch. The economic traits are summarized in Table 1. 
Table 1:- Influence of Chlorella pyrenoidosa and Scenedesmus dimorphus on the economic traits of the silkworm, Bombyx mori.

\begin{tabular}{|c|c|c|c|c|c|c|c|c|}
\hline \multirow{2}{*}{$\begin{array}{l}\text { Concentrati } \\
\text { on } \%\end{array}$} & \multicolumn{8}{|l|}{ Traits } \\
\hline & $\begin{array}{l}\text { Cocoon } \\
\text { Weight } \\
\text { (mg) }\end{array}$ & $\begin{array}{l}\text { Pupal } \\
\text { Weight } \\
\text { (mg) }\end{array}$ & $\begin{array}{l}\text { Shell } \\
\text { Weight } \\
\text { (mg) }\end{array}$ & $\begin{array}{l}\text { Shell } \\
\text { ratio }(\%)\end{array}$ & $\begin{array}{l}\text { Filament } \\
\text { length }(\mathrm{m})\end{array}$ & $\begin{array}{l}\text { Sericin } \\
(\%)\end{array}$ & $\begin{array}{l}\text { Fibroin } \\
(\%)\end{array}$ & Denier \\
\hline \multicolumn{9}{|c|}{ Chlorella pyrenoidosa } \\
\hline Control & $\begin{array}{l}1360 \pm 61.2 \\
0\end{array}$ & $\begin{array}{l}1138 \pm 57.2 \\
0\end{array}$ & $\begin{array}{l}220 \pm 18.8 \\
0\end{array}$ & $\begin{array}{l}16.17 \pm 0 . \\
92\end{array}$ & $\begin{array}{l}794.90 \pm 28.8 \\
4\end{array}$ & $\begin{array}{l}25.60 \pm 1.7 \\
0\end{array}$ & $\begin{array}{l}74.40 \pm 2.3 \\
0\end{array}$ & $\begin{array}{l}2.45 \pm 0.0 \\
6\end{array}$ \\
\hline $2 \%$ & $\begin{array}{l}1545 \pm 48.5 \\
0^{* *}\end{array}$ & $\begin{array}{l}1284 \pm 49.6 \\
2 * *\end{array}$ & $\begin{array}{l}260 \pm 23.5 \\
4 *\end{array}$ & $\begin{array}{l}16.82 \pm 1 . \\
20\end{array}$ & $\begin{array}{l}835.40 \pm 24.7 \\
4 *\end{array}$ & $\begin{array}{l}23.34 \pm 2.4 \\
2\end{array}$ & $\begin{array}{l}76.66 \pm 2.6 \\
2\end{array}$ & $\begin{array}{l}2.78 \pm 0.0 \\
6 * *\end{array}$ \\
\hline $4 \%$ & $\begin{array}{l}1630 \pm 54.6 \\
5 * *\end{array}$ & $\begin{array}{l}1351 \pm 52.4 \\
0 * *\end{array}$ & $\begin{array}{l}278 \pm 20.2 \\
1 * *\end{array}$ & $\begin{array}{l}17.05 \pm 0 . \\
72\end{array}$ & $\begin{array}{l}870.20 \pm 32.6 \\
2 * *\end{array}$ & $\begin{array}{l}20.58 \pm 1.6 \\
8 * *\end{array}$ & $\begin{array}{l}79.42 \pm 2.1 \\
0 * *\end{array}$ & $\begin{array}{l}2.84 \pm 0.0 \\
7 * *\end{array}$ \\
\hline $6 \%$ & $\begin{array}{l}1615 \pm 56.3 \\
6^{* *}\end{array}$ & $\begin{array}{l}1371 \pm 46.2 \\
8 * *\end{array}$ & $\begin{array}{l}242 \pm 10.0 \\
6^{*}\end{array}$ & $\begin{array}{l}14.98 \pm 0 . \\
64^{*}\end{array}$ & $\begin{array}{l}885.25 \pm 25.3 \\
2 * *\end{array}$ & $\begin{array}{l}21.26 \pm 1.8 \\
5^{* *}\end{array}$ & $\begin{array}{l}78.74 \pm 1.9 \\
6 *\end{array}$ & $\begin{array}{l}2.45 \pm 0.1 \\
0\end{array}$ \\
\hline $8 \%$ & $\begin{array}{l}1522 \pm 52.4 \\
2 * *\end{array}$ & $\begin{array}{l}1290 \pm 51.3 \\
4 * *\end{array}$ & $\begin{array}{l}231 \pm 17.4 \\
6^{* *}\end{array}$ & $\begin{array}{l}15.17 \pm 1 . \\
02\end{array}$ & $\begin{array}{l}840.50 \pm 30.1 \\
0^{*}\end{array}$ & $\begin{array}{l}22.85 \pm 2.0 \\
4 *\end{array}$ & $\begin{array}{l}77.15 \pm 2.2 \\
4\end{array}$ & $\begin{array}{l}2.44 \pm 0.0 \\
8\end{array}$ \\
\hline \multicolumn{9}{|c|}{ Scenedesmus dimorphus } \\
\hline $2 \%$ & $\begin{array}{l}1450 \pm 54.0 \\
8^{*}\end{array}$ & $\begin{array}{l}1152 \pm 49.6 \\
0\end{array}$ & $\begin{array}{l}232 \pm 23.8 \\
2\end{array}$ & $\begin{array}{l}16.00 \pm 1 . \\
40\end{array}$ & $\begin{array}{l}810.50 \pm 34.3 \\
5\end{array}$ & $\begin{array}{l}24.00 \pm 1.6 \\
4\end{array}$ & $\begin{array}{l}76.00 \pm 1.8 \\
6\end{array}$ & $\begin{array}{l}2.54 \pm 0.1 \\
1\end{array}$ \\
\hline $4 \%$ & $\begin{array}{l}1470 \pm 48.5 \\
6^{*}\end{array}$ & $\begin{array}{l}1240 \pm 43.7 \\
5^{*}\end{array}$ & $\begin{array}{l}228 \pm 15.2 \\
8\end{array}$ & $\begin{array}{l}15.51 \pm 0 . \\
88\end{array}$ & $\begin{array}{l}860.25 \pm 35.9 \\
6^{*}\end{array}$ & $\begin{array}{l}21.78 \pm 1.9 \\
0 *\end{array}$ & $\begin{array}{l}78.22 \pm 2.6 \\
0 *\end{array}$ & $\begin{array}{l}2.36 \pm 0.0 \\
6 *\end{array}$ \\
\hline $6 \%$ & $\begin{array}{l}1602 \pm 54.3 \\
9 * *\end{array}$ & $\begin{array}{l}1336 \pm 56.3 \\
4 * *\end{array}$ & $\begin{array}{l}264 \pm 21.0 \\
8 * *\end{array}$ & $\begin{array}{l}16.47 \pm 0 . \\
81\end{array}$ & $\begin{array}{l}865.00 \pm 36.4 \\
0 *\end{array}$ & $\begin{array}{l}21.00 \pm 1.8 \\
4 * *\end{array}$ & $\begin{array}{l}79.00 \pm 2.9 \\
4 *\end{array}$ & $\begin{array}{l}2.71 \pm 0.0 \\
9 * *\end{array}$ \\
\hline $8 \%$ & $\begin{array}{l}1586 \pm 62.4 \\
6 * *\end{array}$ & $\begin{array}{l}1323 \pm 45.9 \\
0 * *\end{array}$ & $\begin{array}{l}262 \pm 24.1 \\
5^{*}\end{array}$ & $\begin{array}{l}16.51 \pm 1 \\
00\end{array}$ & $\begin{array}{l}862.50 \pm 25.8 \\
6\end{array}$ & $\begin{array}{l}22.50 \pm 1.9 \\
8 *\end{array}$ & $\begin{array}{l}77.50 \pm 2.0 \\
4\end{array}$ & $\begin{array}{l}2.70 \pm 0.1 \\
0 * *\end{array}$ \\
\hline
\end{tabular}

Mean \pm S.D

*Significant **Highly Significant at $\mathrm{P} \leq 0.05$

All other deviations are not significant.

Table 1 shows that the data of control and algal extract treated MR2 mulberry leaves fed III, IV and V instar B.mori larvae. The economic traits of control B.mori larvae fed with Chlorella pyrenoidosa was Cocoon weight $1360 \pm 61.20$ $\mathrm{mg}$, pupal weight $1138 \pm 57.20 \mathrm{mg}$, shell weight $220 \pm 18.80 \mathrm{mg}$, shell ratio $16.17 \pm 0.92 \%$, filament length $794.90 \pm 28.84 \mathrm{~m}$, fibroin $74.40 \pm 2.30 \%$ and denier $2.45 \pm 0.06$. The maximum cocoon weight, shell weight, shell ratio, fibroin and denier was $1630 \pm 54.65 \mathrm{mg}, 278 \pm 20.21 \mathrm{mg}, 17.05 \pm 0.72 \%, 79.42 \pm 2.10 \%$ and $2.84 \pm 0.07$, When larvae fed with 4 per cent Chlorella pyrenoidosa extract and Pupal weight, filament length, was $1371 \pm 46.28 \mathrm{mg}$ and $885.25 \pm 25.32 \mathrm{~m}$ was observed larvae fed with 6 per cent. Minimum cocoon weight, shell weight and denier was $1522 \pm 52.42 \mathrm{mg}, 231 \pm 17.46 \mathrm{mg}$ and $2.44 \pm 0.08$ were decreased, when the larvae fed with 8 per cent of Chlorella pyrenoidosa extract.

The maximum cocoon weight, pupal weight, shell weight, filament length and fibroin percentage was $1602 \pm 54.39$ $\mathrm{mg}, 1336 \pm 56.34 \mathrm{mg}, 264 \pm 21.08 \mathrm{mg}, 865.00 \pm 36.40 \mathrm{~m}, 79.00 \pm 2.94$ per cent and denier $2.71 \pm 0.09$, respectively, When larvae fed with 6 per cent Scenedesmus dimorphus extract. Minimum cocoon weight, pupal weight, filament length and fibroin was $1450 \pm 54.08 \mathrm{mg}, 1152 \pm 49.60 \mathrm{mg}, 810.50 \pm 34.35 \mathrm{~m}$ and $76.00 \pm 1.86$ per cent were decreased, when the larvae fed with 2 per cent, respectively.

Enriching the silkworm diet (mulberry leaves) with exogenous nutrients such as proteins, carbohydrates, amino acids, vitamins, minerals, hormones, antibiotics and assessing their impact on larval growth, metabolism and silk production has become the order of traditional research in sericulture (Sanappa et al., 2002; Etebari et al., 2004; Bhattacharya and Kaliwal, 2004, 2005). According to Sundararaj, et al. (2000) silkworm reared on the leaf supplemented with soyabean flour to record significantly higher larval weight on the account of the additional protein supplemented.

Kumar et al. (2009) investigated the effect of blue green algae (Spirulina) on cocoon quantitative parameters (cocoon weight, shell weight, pupal weight, shell percentage and silk filament length) of silkworm. The plant 
extracts could benefit sericulture by improving the silk yield of B. mori and commercial silk production (Rajaeshekaragouda et al., 1997). Murugan et al. (1998) noticed a strong correlation between the growth of silkworm and the silk production in the silkworm after the treatment with plant extracts and attributed the growth promoting effect of the plant extracts to the stimulation of biochemical processes leading to protein synthesis.

The present study are comparable with the results of Kuntamalla Sujatha et al. (2015), Jeyapaul et al., (2003) and Kumar et al. (2009). Silkworm diet supplemented with Chlorella and Scenedesmus algal extracts at certain concentration their influence improve growth and economic traits. The economic traits of the silkworm such as cocoon characters (cocoon weight, pupal weight, shell weight, shell ratio, silk characters (filament length, fibroin and denier), were enhanced by extracts. So, this algal supplementation to be beneficial to the farmers to get more quality and quantity of silk yield.

\section{References:-}

1. Amalarani, G., Padmalatha, C., Sornoraj, R. and Ranjithsingh, A.J. (2011): Impact of supplementation of Amway Protein on the economic characters and energy budgets of silkworm B. mori. AJAS, 5(3): 190-195.

2. Balamurugan, R. and Isaiarasu, L. (2007): Effect of the herbal tonic "Iogen" on the growth and cocoon parameters of mulberry silkworm, Bombyx mori L. Proceedings of the National Seminar on Applie Zoology, ANJA College, Sivakasi.

3. Bhattacharya, A. and Kaliwal, B.B. (2005): The Biochemical Effects of Potassium chloride on the Silkworm, Bombyx mori L. Insect. Sci., 12: 95-100.

4. Bhattacharya, A. and Kaliwal, B.B. (2004). Influence of mineral potassium permanganate on the biochemical constituents in the fat body and haemolymph of the silkworm, B. mori L. Int. J. Indust. Entomol., 9(1): 131135.

5. Etebari, K., Ebadi, R. and Mantindoost, L. (2004). Effect of vitamin C on biological, biochemical and economical characteristics of the silkworm, Bombyx mori L. Int. J. Indust. Entomol., 8: 81-87.

6. Etebary, K. and Matindoost, I. (2005). Application of multi vitamins as nutrients on biological and economical characteristics of silk worm , B.mori. I.J Asia pacific Entomol., 8(1):1-6.

7. Guiry, M.D. and Guiry, G.M. (2011). Scenedesmus dimorphus (Turpin) Kützing. AlgaeBase. World-wide electronic publication, National University of Ireland, Galway.

8. Horie, Y., Watanabe, K. and Ito, T. (1967). Nutrition of silkworm B. mori XVIII. Quantitative requirements for potassium, phosphorus, magnesium and zinc. Bull. Seric. Exp. Stn., 22: 181-193.

9. Jeyapaul, C., Padmalatha, C., Ranjitsingh, A.J.A., Murugesan, A.G. and Dhasarathan, P. (2003). Effect of plant extracts on nutritional efficiency in mulberry Silkworm, Bombyx mori. Indian J. of Sericulture. 42(3): 128- 131.

10. Kanafi, R.R., Ebadi, R., Mirhosseini, S.Z., Seindavi, A.R., Zolfaghari, M. and Eteban, K. (2007). A review on nutritive effect of mulberry leaves enrichment with vitamins on economic parameters traits and biological parameters of silkworm, Bombyx mori L. Indian Sericulture Journal. 4: 86-91.

11. Kumar, V., Kumar, D., Kumar, A. and Dhami, S.S. (2009). Effects of blue green algae (spirulina) on cocoon quantitative parameters of silkworm (Bombyx mori L.). APPN Journal of Agricultural and Biological Science. 4(3): 50-52.

12. Kuntamalla Sujatha, Janga Sathish, and Jirra Anitha, (2015). Effect of Medicinal Botanical (Ocimum sanctum), Family, Labiateae on Commercial Parameters of the SilkWorm, Bombyx mori, L. International Journal of Multidisciplinary and Current Research. 3: 76-78.

13. Krishnaswami S. (1978). Improved method of rearing young age (Chawki) silkworms. Bulletin No. 3, CSRTI, Mysore, 1-27.

14. Laskar, N. and Datta, M. (2000). Effect of alfalfa tonic and its organic in gradients on growth and development of silkworm Bombyx mori L. race instar. Environ. Ecol., 18: 591-596.

15. Masthan, K., Kumar, T.R. and Narsimha Murthy, C.V. (2011). Beneficial effects of blue green algae Spirulina and yeast Saccharomyces cerevisiae on cocoon quantitative parameters of silkworm Bombyx mori L. Asian Journal of Microbiology Biotechnology. 13(1): 205-208.

16. Murugan, K., Jayabalan, D., Senthilkumar, N., Senthil Nathan, S. and Sivaprakasam, N. (1998). Growth promoting effect of plant products on silkworm. J. Sci. Ind., 740-745.

17. Pardesh, A.B. and Bajad P.N. (2014). The effect of nutritional supplementation with Amaranthus hybridus L. extract on economic performance of mulberry silkworm, Bombyx mori L. Sch. Acad J Bio sci., 2(4): 272-276.

18. Rajasekaragouda, R., Gopalan, M., Jeyaraj and Natarajan, N. (1997). Field performance of plant extracts on mulberry silkworm, Bombyx mori L. Entomon., 22 (3and4): 235 - 238. 
19. Sanappa, B., Ramaiah, M.J. and Chandrappa, D. (2002). Influence of castor genotype on consumption indices of eri silkworm Sumia cynthia ricini. Bioduval. Environ. Ecol., 20: 960-964.

20. Sheeba, D.V., Padmalatha, C. and Singh, A.J.A.R. (2006). Effect of supplementation of amino acids, leucine and valine on the economic characters of silkworm. J. Zool., 26: 277-280.

21. Singh, K.K., Chauhan, R.M., Panda, A.B., Gokhale, S.B. and Hegdi, N.G. (2005). Effect of use of lactobacillus plantarum as a Probiotics to improve cocoon production of Mulberry silkeorm B.mori. Journal of basic and Applied science., Vol (1): 1-8.

22. Sujatha, K. and Rao, P.A. (2002). Impact of certain 36. phytochemical- substance on the post cocoon characters of Bombyx mori (L) In:- Abstract of National Seminar on mulberry Sericulture Research in India, KSSRDI, Thalaghattapura, Banglore, India, pp. 26-28: 135.

23. Sunder Raj, S., Chinnaswamy, K.P. and Neelu Nangia, (2000). Soyabean to boost cocoon production Indian Silk October. Pp. 11-13.

24. Venkataramana, P., Srinivasa Rao, T.V.S., Srinivasula Reddy, P., Suryanarayana, N. (2003). Effect of Spirulina on the larval and cocoon characters of silkworm, Bombyx mori L. Proc. Nat. Acad. Sci. India., 73(1): 89-94. 